\title{
PENGARUH VARIASI PRODUK, HARGA DAN PROMOSI PENJUALAN TERHADAP KEPUTUSAN KONSUMEN DALAM MEMBELI MOTOR YAMAHA N-MAX DI WONOGIRI
}

\author{
Dwi Warni Wahyuningsih \\ Program Studi Manajemen, Universitas Muhammadiyah, Ponorogo \\ dwiwarnidwiwarni@yahoo.com
}

\begin{abstract}
Abstrak : Penelitian ini bertujuan untuk menganalisis pengaruh variasi produk, harga dan promosi penjualan terhadap keputusan konsumen dalam membeli motor Yamaha N-Max di Wonogiri. Teknik analisis data yang digunakan adalah uji validitas, uji reliabilitas, uji asumsi klasik, analisis regresi linier berganda, uji t, uji $\mathrm{F}$, koefisien determinasi $\left(\mathrm{R}^{2}\right)$. Hasil peneltian menunjukkan variasi produk berpengaruh positif dan signifikan terhadap keputusan pembelian, harga berpengaruh positif dan signifikan terhadap keputusan pembelian dan promosi berpengaruh positif dan signifikan terhadap keputusan pembelian. Secara simultan variasi produk, harga dan promosi memiliki pengaruh signifikan terhadap keputusan pembelian.
\end{abstract}

Kata kunci : variasi produk, harga, promosi, keputusan konsumen.

\section{PENDAHULUAN}

Kemajuan teknologi yang semakin berkembang memberikan kenyamanan bagi manusia. Pesatnya perkembangan teknologi, menjadikan manusia sebagai makhluk yang memiliki kebutuhan tak terbatas, berharap akan selalu ada teknologi baru yang akan memenuhi kebutuhan mereka. Namun, konsumen akan selektif dalam mengkonsumsi barang atau jasa yang mereka inginkan untuk memenuhi kebutuhan mereka. Juga tidak ada kebutuhan untuk pemenuhan fasilitas transportasi yang saat ini banyak diinginkan untuk dipenuhi oleh setiap orang. Motor itu merupakan salah satu hasil kemajuan teknologi di bidang otomotif. Dilihat dari ukuran, harga, dan pengoperasian, motor merupakan sarana transportasi yang sangat praktis. Orangorang menggunakan motor untuk membantu kegiatan mereka baik pekerjaan, perdagangan, dan berbagai kegiatan lain yang membutuhkan transportasi.

Pertumbuhan penggunaan motor dalam dekade saat ini sangat cepat sesuai dengan perkembangan teknologi di dunia otomotif, sehingga tidak mengherankan bahwa persaingan dalam penjualan motor berlangsung sangat ketat dan harga yang ditawarkan kompetitif, ini tidak hanya terbatas untuk penjualan motor tetapi bentuk, akselerasi, aksesoris, warna dan kecanggihan teknologi yang menyertainya. Harga jual motor saat ini sangat kompetitif, bahkan pabrikan tidak terbatas pada memproduksi motor untuk kelas menengah ke atas, tetapi sekarang pabrikan mulai memproduksi motor dengan harga murah dan dapat dijangkau oleh kelas menengah ke bawah. Keputusan harga yang kompetitif akan membuat konsumen lebih mudah dalam menentukan keinginan mereka untuk membeli motor.

Kebutuhan motor yang tinggi membuat semakin banyak pabrikan berlomba-lomba untuk memproduksi motor sehingga dapat meningkatkan persaingan antar produsen. Dalam persaingan yang semakin ketat dari produsen motor seperti saat ini, di mana konsumen diharapkan dalam berbagai pilihan alternatif produk yang ditawarkan, para produsen dituntut untuk selalu mengikuti perkembangan pasar sebagai dasar pengambilan keputusan.

Pasar merupakan faktor penting untuk mencapai aktivitas bisnis yang sukses. Tujuan perusahaan dapat dicapai dengan menguasai pasar sehingga harus diketahui dan dipahami tentang konsep pemasaran, yaitu filosofi bisnis yang menyatakan bahwa kepuasan pelanggan merupakan syarat ekonomi dan sosial untuk kelangsungan hidup perusahaan. Konsep pemasaran 
mengajarkan bahwa kegiatan pemasaran suatu perusahaan harus dimulai dengan kegiatan untuk mengidentifikasi dan merumuskan keinginan dan kebutuhan konsumen.

Pemahaman perilaku konsumen dalam membeli suatu produk akan sangat bermanfaat bagi perusahaan dalam menentukan dan mengembangkan produk yang akan dibuat. Perusahaan harus mempelajari perilaku konsumen dari target pasar yang dituju sehingga produk yang dihasilkan mendapat respons efektif dari konsumen. Penelitian tentang siapa yang ada di pasar konsumen, apa yang dibeli konsumen, ketika mereka membeli, siapa yang terlibat dalam pembelian, mengapa konsumen membeli dan bagaimana mereka membeli adalah analisis pasar yang terkait erat dengan konsumen. Konsumen akan menuntut berbagai produk sehingga akan ada banyak pilihan bagi konsumen untuk menentukan produk yang akan dibeli. Bagi konsumen, variasi produk akan menentukan keputusan mereka untuk membeli produk.

Selain variasi produk, konsumen akan mempertimbangkan harga dalam menentukan keinginan mereka untuk membeli produk. Dengan harga yang kompetitif dan cenderung lebih murah daripada yang lain maka akan membuat konsumen lebih mudah memutuskan untuk membeli produk. Harga yang ditentukan untuk motor yang dijual tentu saja harus memenuhi elemen yang tepat, karena harga yang tepat dilihat dari kualitas produk. Produk berkualitas tepat jika harganya terlalu mahal dan konsumen tidak keberatan membayar untuk produk tersebut. Demikian juga, konsumen akan kecewa jika mereka harus membayar untuk produk-produk berharga murah yang berkualitas rendah. Itulah yang dikatakan bahwa harga akan membuat konsumen mudah membeli produk yang ditawarkan untuk produk ini.

Dalam pemasaran dealer motor akan melakukan berbagai promosi melalui media cetak, elektronik dan lainnya. Promosi yang dilakukan oleh dealer ini dengan harapan mampu membawa konsumen untuk datang membeli produk yang ditawarkan. Melalui promosi produk ini, konsumen akan lebih mudah membuat keputusan untuk membeli suatu produk; dari promosi yang ada tentang produk akan dijelaskan tentang manfaat produk sehingga konsumen menjadi sadar akan produk yang akan dibeli.

Untuk berhasil penjualan motor dealer motor di Wonogiri, berbagai kebijakan digunakan untuk melayani konsumen, termasuk harga, variasi dalam produk kompetitif dibandingkan dengan yang lain, karena mereka adalah produk unggulan. Faktor lain adalah promosi yang lebih intens sehingga penjualan motor akan meningkatkan penjualan.

\section{KAJIAN PUSTAKA \\ Perilaku konsumen}

Pengusaha yang ingin sukses harus memperhatikan dan memahami kebutuhan konsumen. Konsumen memiliki perbedaan dalam hal keinginan, kebutuhan, pendidikan, pekerjaan, dan tingkat pendapatan, sehingga perilaku mereka juga bervariasi. Perilaku konsumen adalah reaksi terhadap kebutuhan dan keinginan baik secara naluriah maupun karena pengaruh lingkungan sekitarnya. Perilaku atau perilaku muncul karena berbagai kondisi yang mempengaruhi konsumen. Hal ini mengakibatkan konsumen mencari alternatif yang dapat memberikan kepuasan dan manfaat baginya. Setelah menentukan alternatif terbaik menurutnya, maka konsumen mulai mempertimbangkan untuk mengambil keputusan pembelian.

Perilaku konsumen adalah kegiatan individu yang secara langsung melibatkan untuk mendapatkan dan menggunakan barang dan jasa, termasuk proses pengambilan keputusan yang diambil tentang persiapan dan penentuan kegiatan tersebut (Basu Swastha dan T. Hani handoko, 2009: 10).

Berdasarkan perilaku konsumen di atas, dapat disimpulkan bahwa perilaku konsumen adalah suatu tindakan yang dilakukan oleh individu, kelompok, atau organisasi yang berkaitan dengan proses penentuan keputusan untuk mendapatkan, menggunakan barang dan jasa ekonomi yang dapat dipengaruhi oleh lingkungan. Dari definisi ini, elemen penting dari perilaku 
konsumen dapat diambil, yaitu proses pengambilan keputusan dan kegiatan yang semuanya melibatkan individu dalam menilai, memperoleh barang dan jasa ekonomi.

\section{Keputusan Pembelian Produk}

Pengambilan keputusan dan perilaku yang mempengaruhinya, ini adalah sistem. "Sistem adalah totalitas atau keseluruhan yang terdiri dari bagian-bagian yang saling berhubungan, bekerja sama untuk mencapai tujuan yang dinyatakan" (H. Buchari Alma, 2007: 102). Keputusan membeli dapat diartikan sebagai berikut ;

Pengambilan keputusan pembelian adalah keputusan untuk membeli seseorang yang asalnya dipengaruhi oleh lingkungan, budaya, keluarga dan sebagainya, akan membentuk sikap pada individu, kemudian melakukan pembelian ( Buchari Alma, 2007: 102).

Adapun tahapan dalam proses pengambilan keputusan pembelian, sebagai berikut:

a. Kebutuhan pengakuan

b. Pencarian informasi

c. Alternatif evaluasi

d. Keputusan pembelian

e. Perilaku pasca pembelian.

Pengambilan keputusan oleh konsumen untuk membeli suatu produk dimulai dengan kesadaran akan kebutuhan. Selanjutnya, jika Anda telah menyadari kebutuhan dan keinginannya, maka konsumen akan menemukan informasi tentang keberadaan produk yang mereka inginkan. Proses pencarian informasi ini akan dilakukan dengan mengumpulkan semua informasi yang terkait dengan produk yang diinginkan. Dari berbagai informasi yang diperoleh konsumen, pemilihan alternatif tersedia. Proses pemilihan ini disebut tahap evaluasi informasi. Dengan menggunakan berbagai kriteria yang ada di benak konsumen, satu merek produk dipilih untuk dibeli (Sutisna , 2010: 15).

Dengan pembelian merek produk tertentu, proses evaluasi belum berakhir karena konsumen akan melakukan evaluasi pasca pembelian. Proses ini akan menentukan apakah konsumen merasa puas atau tidak atas keputusan pembelian mereka. Jika konsumen merasa puas, maka kemungkinan untuk membeli kembali di masa depan akan terjadi, sementara konsumen tidak puas dengan keputusan pembelian, ia akan mencari informasi produk yang ia butuhkan, ia akan mencari informasi produk yang ia butuhkan. Proses akan berlanjut hingga konsumen merasa puas dengan keputusan untuk membeli produk (Sutisna , 2010: 16).

\section{Hipotesis}

a. Variasi produk berpengaruh signifikan terhadap keputusan konsumen dalam membeli motor Yamaha N-Max di Wonogiri.

b. Harga berpengaruh signifikan terhadap keputusan konsumen dalam membeli motor Yamaha N-Max di Wonogiri.

c. Promosi berpengaruh signifikan terhadap keputusan konsumen dalam membeli motor Yamaha N-Max di Wonogiri.

d. Variasi produk, harga, dan promosi memiliki pengaruh signifikan terhadap keputusan konsumen dalam membeli motor Yamaha N-Max di Wonogiri bersama.

\section{METODE PENELITIAN}

\section{Ruang lingkup penelitian}

Jenis penelitian ini adalah penelitian kuantitatif dengan metode survei. Oleh karena itu penelitian ini dilakukan dengan survei di Wonogiri. 


\section{Sumber data}

a. Data utama

Data primer adalah data yang dikumpulkan dan diperoleh langsung oleh peneliti di lapangan dengan melakukan survei yang dilakukan menggunakan kuesioner (kuesioner).

b. Data sekunder

Data sekunder adalah data yang diperoleh secara tidak langsung oleh peneliti. Data sekunder ini misalnya dicari melalui data dokumentasi yang telah direkam oleh perusahaan yang sedang dipelajari, buku, majalah, informasi atau publikasi lainnya. Data sekunder yang digunakan dalam penelitian ini adalah teori teori yang diambil dari buku-buku pendukung.

\section{Definisi Operasional Variabel}

a. Variasi produk

Variasi produk adalah berbagai jenis produk yang ditawarkan untuk dipilih dan dibeli oleh konsumen. Indikator variasi produk adalah kemudahan mendapatkan produk, kelengkapan produk dan keinginan untuk membeli. Skala pengukuran yang menggunakan skala Likert. Variasi produk variabel terdiri dari lima item pertanyaan.

b. Harga

Harga adalah jumlah uang yang diberikan untuk mendapatkan sepeda motor yang diinginkan. Indikatornya terjangkau, standar, relatif, bervariasi, dan stabil. Pengukuran adalah skala menggunakan skala Likert. Kuesioner harga terdiri dari lima item pertanyaan.

c. Promosi

Promosi adalah kegiatan pemasaran yang dilakukan oleh perusahaan untuk meningkatkan penjualan. Indikatornya adalah iklan, penjualan pribadi, sistem pembayaran, dan harga diskon. Skala pengukuran yang menggunakan skala Likert. Variabel promosi terdiri dari lima item pertanyaan.

d. Keputusan konsumen untuk membeli motor

Keputusan yang konsumen untuk membeli motor adalah suatu tindakan konkret yang diambil oleh konsumen untuk membuat keputusan untuk membeli motor. Indikatornya adalah faktor lingkungan (teman dan tetangga), atas keinginan mereka sendiri, produk, pengaruh keluarga, dan iklan. Skala pengukuran ini menggunakan scala Likert . Keputusan konsumen dalam membeli pertanyaan kuesioner motor terdiri dari lima item pertanyaan.

\section{Populasi dan Sampel}

a. Populasi

Populasi terdiri dari seperangkat objek yang merupakan pusat informasi yang ingin diambil datanya (W. Gulo , 2012: 76). Dalam penelitian ini populasi adalah konsumen motor Yamaha N-Max pada Mei 2019.

b. Sampel

Sampel adalah bagian dari suatu populasi (W. Gulo , 2012: 78). Sampel yang digunakan dalam penelitian ini adalah sejumlah 50 orang konsumen motor Yamaha N-Max pada Mei 2019.

c. Tipe data

- Data kualitatif adalah data penelitian dalam bentuk tanggapan, pendapat, sikap atau karakteristik seseorang atau sekelompok orang yang menjadi responden. Hasil data responden kemudian dikonversi menjadi data kuantitatif menggunakan skala likert.

- Data kuantitatif adalah data yang dapat diukur dengan skala numerik (angka).

d. Prosedur Pengumpulan Data

- Daftar pertanyaan

Pengumpulan data dilakukan dengan kuesioner. Kuisioner atau kuisioner adalah cara pengumpulan data dengan memberikan daftar pertanyaan yang telah disiapkan 
sebelumnya oleh peneliti sesuai dengan indikator pada variabel yang diteliti. Kuisioner ini digunakan untuk memperoleh data yang akan dianalisis terhadap variabel yang diteliti.

- Pengamatan

Observasi adalah cara pengumpulan data dengan melakukan pengamatan langsung terhadap ruang untuk melengkapi data yang diperoleh.

- Dokumentasi

Dokumentasi adalah metode pengumpulan data dengan menyalin data yang direkam oleh pihak-pihak tertentu. Data dokumentasi ini digunakan untuk mendukung kelengkapan data dalam penelitian.

e. Teknik analisis data

Uji Instrumen

1) Uji Validitas

Uji validitas adalah ukuran yang menunjukkan tingkat validitas atau validitas suatu instrumen. Instrumen yang valid atau valid memiliki validitas tinggi, sedangkan instrumen yang kurang valid atau valid memiliki validitas rendah. (Suharsimi Arikunto, 2012: 160). Suatu instrumen dikatakan valid jika mampu mengukur apa yang diinginkan. Suatu instrumen dikatakan valid jika dapat mengungkapkan data dari variabel yang diperiksa dengan tepat.

2) Uji reliabilitas

Menurut Suharsimi Arikunto (2012: 162) menyatakan "uji dikatakan dapat diandalkan jika memberikan hasil yang tetap ketika dilakukan berulang kali". Untuk menguji reliabilitas menggunakan teknik Alpha Cronbach (Suharsimi Arikunto, 2012: 192).

3) Uji asumsi klasik

a) Uji Multikolinearitas

Multikolinearitas adalah hubungan linear yang sempurna atau pasti antara beberapa atau semua variabel independen dari model regresi. Uji multikolinieritas bertujuan untuk menguji apakah model regresi menentukan korelasi antara variabel independen. Aturan yang digunakan untuk mendeteksi ada atau tidaknya multikolinieritas dapat dilihat dari nilai nilai toleransi dan variance inflation factor (VIF), jika nilai toleransi kurang dari 0,10 atau nilai VIF di bawah 10 berarti multikolinieritas ( Ghozali Imam, 2010 : 87).

b) Uji normalitas

Uji normalitas bertujuan untuk menguji apakah variabel dependen dan variabel independen memiliki distribusi normal atau tidak. Uji Normalitas menggunakan uji Kolmogorov - Smirnov, dengan tes ini dapat diketahui bahwa data yang digunakan terdistribusi normal atau tidak.

c) Uji heterokedastisitas

Uji heterokedastisitas bertujuan untuk menguji apakah dalam model regresi ada ketidakpastian varians residual satu pengamatan ke pengamatan lain. Metode yang digunakan untuk menguji gejala ini Glejser, untuk residual absolut, maka, itu regresi nilai sisa mutlak diperoleh sebagai variabel dependen dan regresi dari variabel independen.

4) Pengujian hipotesis

a) Analisis Regresi Linier Berganda

Analisis regresi linier berganda ini digunakan untuk mengetahui pengaruh variabel independen, yaitu variasi produk, harga dan promosi terhadap variabel dependen keputusan konsumen dalam membeli motor, dengan rumus:

$$
\mathrm{Y}=\mathrm{a}+\mathrm{b} 1 \mathrm{x} 1+\mathrm{b} 2 \mathrm{X} 2+\mathrm{b} 3 \mathrm{X} 3+\mathrm{e}
$$


b) uji t

Tes ini adalah untuk menguji tingkat signifikansi pengaruh masing-masing atau sebagian variabel independen (variasi dalam produk, harga dan promosi) dari variabel dependen (keputusan konsumen untuk membeli motor).

c) uji $\mathrm{F}$

Uji F digunakan untuk menentukan pengaruh variabel independen (variasi produk, harga, dan promosi) terhadap variabel dependen (keputusan konsumen untuk membeli motor) secara bersama-sama.

d) Uji Koefisien Determinasi $\left(\mathrm{R}^{2}\right)$

Koefisien determinasi adalah untuk menentukan tingkat pengaruh dalam bentuk persentase variabel independen (variasi produk, harga dan promosi) terhadap variabel dependen (keputusan konsumen dalam membeli motor), menggunakan rumus analisis determinasi $\left(\mathrm{R}^{2}\right)$.

\section{HASIL PENELITIAN}

Pengaruh keputusan pembelian terhadap variabel variasi produk memiliki pengaruh yang signifikan. Ini berarti bahwa setiap variasi produk tambahan yang dibuat oleh perusahaan akan meningkatkan keputusan pembelian konsumen. Keragaman produk akan membuat pembeli lebih mudah menentukan pilihan produk yang akan dibeli. Variasi produk yang disediakan oleh perusahaan antara lain kemudahan mendapatkan produk yang bervariasi dari perusahaan ke berbagai pilihan variasi produk, perusahaan menyediakan berbagai produk dan ada keinginan untuk membeli dari konsumen karena beragamnya produk yang tersedia.

Variabel harga mempengaruhi keputusan pembelian. Konsumen dalam membeli harga produk merupakan prioritas untuk menentukan pembelian produk, harga juga menjadi dasar konsumen untuk mengetahui perbandingan kualitas produk dan nilai manfaat yang diberikan. Harga yang diberikan oleh perusahaan untuk menarik konsumen memutuskan untuk membeli adalah dengan harga terjangkau, harga standar, harga relatif, bervariasi dalam menentukan harga produk, dan harga dibuat stabil fluktuasi dalam nilai tukar sistem kenaikan harga, harga tidak ikuti fluktuasi dolar di pasar .

Konsumen memahami produk karena promosi yang dilakukan oleh perusahaan. Dalam penelitian ini promosi memiliki pengaruh signifikan terhadap keputusan pembelian, itu berarti bahwa semakin baik promosi dan promosi yang lebih menarik itu akan membuat konsumen lebih mudah memutuskan pembelian produk. Promosi oleh perusahaan termasuk iklan dengan membuat iklan di berbagai media baik elektronik, media massa dan sebagainya, promosi melalui penjualan pribadi juga masih dipilih oleh perusahaan karena penjualan motor akan efektif jika didukung oleh tenaga penjualan karena mereka dapat lebih spesifik dalam menjelaskan detail produk kepada pelanggan, pembayaran sistem, dan diskon harga.

\section{KESIMPULAN}

a. Hasil uji $F$ dikenal sebagai Sig. sama dengan 0,000 kurang dari 0,05 atau sig. $=0,000<0,05$, jadi Ho ditolak sehingga dapat disimpulkan bahwa variasi produk, harga dan promosi memiliki pengaruh yang signifikan secara bersama-sama pada keputusan pembelian.

b. Variabel variasi produk $\left(\mathrm{X}_{1}\right)$ memiliki pengaruh positif dan signifikan terhadap variabel keputusan pembelian (Y).

c. Variabel harga $\left(\mathrm{X}_{2}\right)$ memiliki pengaruh positif dan tidak signifikan terhadap variabel keputusan pembelian (Y).

d. Variabel promosi $\left(\mathrm{X}_{3}\right)$ memiliki pengaruh positif dan signifikan terhadap variabel keputusan pembelian (Y). 
e. Koefisien determinasi $\left(\mathrm{R}^{2}\right)$ diketahui bahwa keputusan pembelian $68,6 \%$ ditentukan oleh variasi produk, harga dan promosi sedangkan sisanya 31,4\% dipengaruhi oleh variabel lain di luar variabel yang diteliti.

\section{Saran}

a. Perusahaan perlu menambahkan lebih banyak variasi produk sehingga konsumen memiliki lebih banyak kesempatan untuk membuat pilihan saat membeli. Variasi produk yang dapat dibuat dari jenis, warna dan sebagainya.

b. Untuk memperhatikan harga keputusan pembelian, harga dari faktor yang tepat adalah bahwa harga dari faktor yang tepat adalah bahwa konsumen merasa tertarik untuk melakukan pembelian.

c. Hasil promosi menunjukkan pengaruh yang signifikan dan juga dominan pada keputusan pembelian, untuk itu dealer harus mempertahankan promosi yang telah ditingkatkan sehingga penjualan meningkat.

\section{DAFTAR PUSTAKA}

Aguinis, Herman and Kraiger, Kurt. 2009. "Benefits of Training and Development for Individuals and Teams, Organizations and Society". The Annual Review of Psychology. 2009. No. 60, pp: 451-474.

Cardinali, Silvio; Luca, Gian, Gregori dan Palanga, Paola. 2014. "SFA Adoption: Empirical Evidences from A Case Study". International Journal of Business and Social Research. Vol. 4, No. 6, pp: 123-136.

Challagalla, Goutam, N., and Shervani, A., Tassaduq. 1996. "Dimension and Types of Supervisory Control: Effect on Salesperson Performance and Satisfication”. Journal of Marketing. Vol. 60, No.1, pp: 89-105.

Elly, Aprillia, K., and Mursid, Ali. 2015. "Pengaruh Pengawasan, Kepuasan pada Pimpinan, dan Komitmen Tenaga Penjual pada Kinerja Tenaga Penjual”. Jurnal EBBANK. Vol. 6, No. 1, pp: 19-32.

Honeycutt, Earl, D.; Jr., Thelen, Tanya; Thelen, Shawn T., dan Hodge, Sharon K. 2005. "Impediments to Sales Force Automation". Industrial Marketing Management. Vol. 34, No. 4, pp: 313-322.

Jayachandran, S., Sharma, S., Kaufman, P., and Raman, P. (2005). The Role of Relational Information Processes and Technology use in Customer Relationship Management. Journal of Marketing. Vol. 94, No. 4, pp: 177-192.

Kalalo, Rinny, E. 2013. Customer Relationship Management dan Kualitas Pelayanan Pengaruhnya terhadap Loyalitas Konsumen PT. Matahari Dept. Store, Manado. Jurnal EMBA. Vol. 1, No.4, pp: 1553-1561.

Michel, Jean, Moutot and Bascoul, Ganael. 2008. "Effects of Sales Automation use on Sales Force Activities and Customer Relationship Management Processes". Journal of Personal Selling \& Sales Management. Vol. 28, No. 2, pp: 167-184.

Onna, Anatasha, C.; Fauzi, Achmad., and Kumadji Srikandi. 2014. Penerapan Customer Relationship Management (CRM) Sebagai Upaya untuk Meningkatkan Loyalitas 
Pelanggan (Studi Kasus pada Bandung Sport Distro Malang). Jurnal Administrasi Bisnis (JAB). Vol. 15, No. 1, pp: 1-11.

Ridwan, Muhammad; Fudholi, Achmad; and Prasetyo, Edy, Nugroho. 2012. Pengaruh Desain Organisasi, Gaya Kepemimpinan dan Iklim Kerja terhadap Kinerja Karyawan. Jurnal Manajemen dan Pelayanan Farmasi. Vol. 2, No. 3, pp: 171-177.

Sabir, R. I; Rehman, A.; Bahadur, W.; Aziz, S., and Ejaz, K. 2013. "Impact of Sales Force Automation on Relationship Quality and Sales Force Performance". Journal of Basic and Applied Scientific Research. Vol. 3, No. 12, pp: 1-7.

Smith, Kirk; Eli, Jones and Edward, Blair. 2000. "Managing Sales Person Motivation in a Territory Realignment". Journal of Personal Selling \& Sales Management. Vol. 20, No 4, pp: 215-226.

Theresia, Dorkas, T. 2006. Analisis Pengaruh Sistem Kontrol dan Sales Training terhadap Kinerja Tenaga Penjualan untuk Meningkatkan Efektivitas Penjualan (Studi Kasus Pada Bank ABN AMRO di Semarang). Tesis. Semarang: Universitas Diponegoro. 